UDC 634.2-153.5; 631.87

COBISS.SR-ID: 219343884

Original research paper

Acta Agriculturae Serbica, Vol. XX, 39 (2015); 75-83

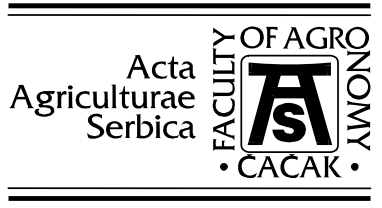

\title{
Investigation of the possibility for production of some stone fruit rootstocks by rooting cuttings
}

\author{
Aleksandar Markovski, Melpomena Popovska, Viktor Gjamovski \\ Institute of Agriculture-Skopje, Ss. Cyril and Methodius University in Skopje, \\ Skopje, R. Macedonia.
}

\begin{abstract}
This work evaluated the influence of different biostimulators (IBA and NAA) on rooting softwood and hardwood cuttings from some stone fruit rootstocks (Mirabolana, St. Julian A., St. Julian INRA, St. Julian Orleans, GF 8/1, GF 655/2, Alkavo, Gisela 4, Gisela 5, Weiroot 53 and Weiroot 158). The experiment was conducted in an experimental greenhouse at the Institute of Agriculture, Skopje. Rooting biostimulators were applied in 3 variants: a) IBA $2 \%$, b) NAA $0.2 \%$, c) IBA $2 \%$ without chemical protection. The GF/8 rootstock had the highest percent of rooted cuttings $(50.8 \%$ ), while some rootstocks (Weiroot 158 and Wieroot 53) produced negligible rooting of the cuttings $(1.6 \%)$. Hardwood cuttings from the tested rootstocks had better rooting $(20.3 \%)$ than softwood cuttings $(6.0 \%)$. The first treatment (IBA $2 \%$ ) was the most efficient for rooting cuttings $(23.1 \%)$.
\end{abstract}

Key words: softwood cutting, hardwood cutting, rooting.

Received: 11 September 2015 / Accepted: 18 October 2015 
Acta Agriculturae Serbica, Vol. XX, 39 (2015); 75 - 83

\section{Introduction}

Rooting cuttings from fruit trees is the simplest, fastest and cheapest way of producing uniform and quality rootstocks. Unlike rootstocks from other fruit trees, rootstocks for stone fruits are rarely or never propagated vegetatively in the usual ways. Rootstocks are highly effective in reducing vigor, balancing growth and yield, and contributing to compatibility, resistance to the economically important diseases and pests, and adaptability to agroecological conditions (Markovski, 2012a). Stone fruit varieties are generally propagated by grafting, or budding on seedlings. In the last decades there has been a tendency to propagate stone fruit cultivars on vegetative rootstocks to overcome some aspects due to the use of generative rootstocks, such as lack of uniformity with respect to vigor, and compatibility and late setting of fruits (Ancu et al. 2009). The basic propagation of stone trees is performed by grafting on rootstocks derived from seeds, which provide plants with pivotant roots, whereas vegetative propagation induces fasciculate and superficial roots (Markovski, 2012b). The vegetative propagation, especially micropropagation (in vitro), significantly reduces the transfer of viruses (Lopez-Bucio, 2003).The root system of stone fruit trees is characterized by a specific structure. They have extreme taproot and root branching in deeper soil layers. The root system is essential for many plant adaptive functions including water and nutrient uptake, soil fixation and stabilization of biotic interactions in the rhizosphere. Changes in the root architecture of the rootstock might severely affect plant capacity to water and nutrient uptake (Castro, 2003). The root flare in stone fruit trees is characterized by weakly expressed rhisogenesis, which excludes the use of propagation with mound or stool layers, another basic method for pome fruit rootstock propagation. Among plant propagation methods, air layering has also been used in plant propagation (Fachinello, 1996). Air layering is a process of asexual multiplication where the originating plant is only detached from the mother plant after its root formation (Fachinello, 2005). The scion cultivar 'Granada' grafted on the following peach rootstocks (Prunus persica (L.) Batsch): Aldrighi, Capdeboscq and Okinawa show that the peach cultivar ('Granada') on rootstocks propagated by air layering has similar or superior yield and the same attributes of fruit quality compared to using rootstocks derived from seeds. However, the root system of the rootstocks for stone fruits obtained from layers is characterized by a weak root architecture, due to the connection with the mother tree and absorption of nutrients through it. The importance of root architecture on plant yield rests on the fact that soil resources are unevenly distributed or are subject to located exhaustion; and thus the spatial distribution of the roots becomes a significant measurement to determine the exploration capacity of these resources (Lynch, 1995). Therefore, the best vegetative method for stone fruit rootstock propagation, which can annul numerous shortcomings of generative methods of propagation, is by the rooting of cuttings. Giorgi et al. (2005) highlight the importance of a precise evaluation 
Acta Agriculturae Serbica, Vol. XX, 39 (2015); 75 - 83

of rootstocks and scions as well as the identification of their best combinations, since peach rootstocks have some influence on scion cultivar performance (Zarrouk, 2005). Although applying it to cultivars with more than 50\% rooting rate can be economical (Hartmann, 1997), an improvement in propagation technology is needed, and research on environmental factors and some biochemical features of mother plants at the time of cutting collection could contribute to the progress. Rooting is a complex process determined by the interrelationship of many factors. Rooting rate is highly influenced by the time of cutting collection, which includes the state of the mother plant and environmental factors on that day (Szecskó, 2006). This experiment was set up to determine the best time, biostimulator concentration and genotype for the rooting of cuttings from stone fruit rootstocks.

\section{Materials and methods}

During 2004-2006, research was conducted on the rooting ability of hardwood and softwood cuttings of rootstocks for stone fruits (Mirabolana, St. Julian A., St. Julian INRA, St. Julian Orleans, GF 8/1, GF 655/2, Alkavo, Gisela 4, Gisela 5, Weiroot 53 and Weiroot 158). One-year-old cuttings (both hardwood and softwood), from five-year-old rootstock mother trees were used for rooting. The hardwood cuttings had an average length of $20-25 \mathrm{~cm}$, and width of 6-8 $\mathrm{mm}$. They were set at the beginning of spring (March), while softwood cuttings were 10-15 cm long, with 1-3 leaves, and were set in June. The cuttings (both hardwood and softwood) were set in four variants: 1- control (without biostimulator); 2- treated with biostimulator $2 \%$ IBA $\left(\mathrm{C}_{12} \mathrm{H}_{13} \mathrm{NO}_{2}\right.$ (Indole-3butyric acid)) in talc carrier; 3- treated about 10 seconds with $0.2 \%$ liquid solution of biohormone NAA $\left(\mathrm{C}_{10} \mathrm{H}_{7} \mathrm{CH}_{2} \mathrm{CO}_{2} \mathrm{H}\right.$ (1-Naphthaleneacetic acid)) and 4 - treated with IBA $2 \%$, without protection. The cutting basal part of the cuttings was treated.

In variants 1, 2 and 3, protection with an appropriate solution of Previcur and Benomil was performed immediately after the cuttings set, at 10-12 day intervals.

The cuttings were rooted in $10 \mathrm{~cm}$ deep cleaned river sand, at a distance of $15 \times 10 \mathrm{~cm}$ between the cuttings under greenhouse conditions with an optimal air temperature and $80-90 \%$ relative humidity maintained by an automatic mist system. The rooting percent was calculated after removal of the cuttings from the substrate at the end of vegetation.

The data were statistically analyzed by ANOVA and Fisher's multiple comparison test at a level of 0.05 using the Minitab software. 
Acta Agriculturae Serbica, Vol. XX, 39 (2015); 75 - 83

\section{Results and Discussion}

The mother plants from which the cutting material was collected were in excellent condition, and had no presence of important diseases and pests. The investigation of hardwood cuttings shows that rootstocks for plum and peach (Mirabolana, St. Julian A., St. Julian INRA, St. Julian Orleans, GF 8/1, GF $655 / 2)$ are characterized by a satisfactory rooting percent $(31.3 \%)$ unlike cherry and sour cherry rootstocks (Alkavo, Gisela 4, Gisela 5, Weiroot 53 and Weiroot 158) (5.4\%). The GF $8 / 1$ rootstock exhibits a higher rooting percent of hardwood cuttings $(50.8 \%)$. Treatment with auxin IBA $2 \%$ had the greatest effect on the rooting of hardwood cuttings $(27.7 \%)$. NAA $0.2 \%$ showed a weak effect on rooting $(17.7 \%)$ compared with the control $(25.3 \%)$. The highest rooting of hardwood cuttings was found at the GF 8/1 rootstock treated with IBA $(62.7 \%)$ (Fig.1). The Mirabolana rootstock had the second highest rooting percent in the treatment with IBA $(52.6 \%)$. This rootstock exhibited the highest increase in the rooting percent $(+23.8 \%)$ compared with the control, as the result of auxin IBA action unlike the other rootstocks (Fig.1).

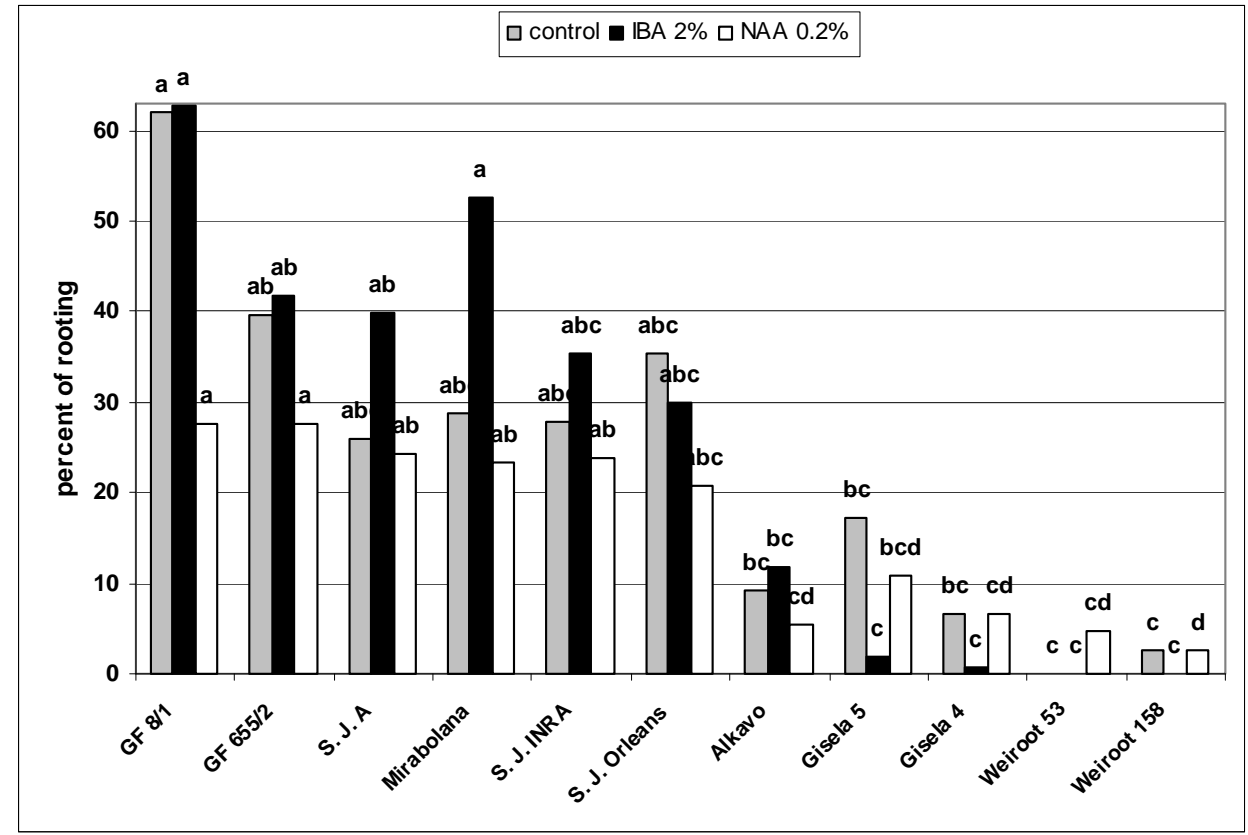

Fig.1. Rooting of hardwood cuttings (\%).

Among the rootstocks for plum and peach, only St. Julian Orleans was negatively affected by IBA treatment, in contrast to cherry and sour cherry rootstocks, with only Alkavo being positively affected by IBA treatment or greater percent rooting recorded, compared with the control. 
Acta Agriculturae Serbica, Vol. XX, 39 (2015); 75 - 83

The results show that the combined effect of genotype and treatment was great, but statistically non-significant, especially compared with separate rootstock groups (for plum/peach, and for cherry/sour cherry). Therefore, no statistically significant differences were observed among rootstocks for plum/peach or among those for cherry/sour cherry (Fig.1).

A positive effect of protection agents on rooting percent was found, with some exceptions. When rooting cuttings of rootstocks that are more disease and pest sensitive (Sent Julien rootstocks), benefits are greater for the use of protection agents due to the clear increase in rooting percent. The GF 8/1 rootstock showed a higher rooting percent $(70 \%)$, when hardwood cuttings were not treated with protection agents.

This research showed that the rooting ability of softwood cuttings on the same tested rootstocks was on average considerably lower $(6 \%)$ compared with the rooting of hardwood cuttings $(24 \%)$. Statistical significance and the highest rooting percent were found for the GF 8/1 rootstock (36.0\%). The softwood cuttings from this rootstock had an almost equal rooting percent across treatments (control 33\%, IBA 37\%, NAA 38\%) unlike the rooting of hardwood cuttings (control 62\%, IBA 63\%, NAA 28\%). There was even the highest positive effect of the auxin NAA, which was not the case in the experiment with hardwood cuttings (Fig. 2.). Interestingly, among the rootstocks for plum/peach (particularly among St. Julian Orleans cuttings), a negative influence of auxin treatments on the rooting percent was again recorded, as with the rooting of hardwood cuttings. A statistically significantly higher rooting percent was found in the control of the St. Julian Orleans rootstock compared with the other rootstocks, with the exception of GF 8/1 (Fig.2.).

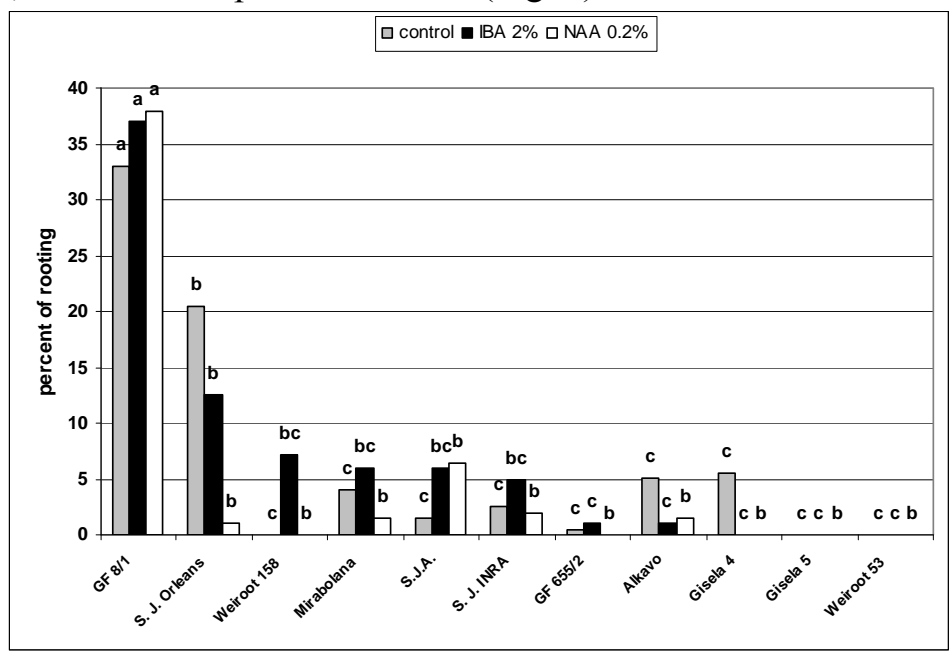

Fig.2. Rooting percentage of softwood cuttings. 
Acta Agriculturae Serbica, Vol. XX, 39 (2015); 75 - 83

The quality of the rooted softwood cuttings was noticeably lower compared with hardwood cuttings. A relatively loose connection between rooting and physiological factors, leaf fall and sprouting was found in some rootstocks (GF 8/1, Sainte Julien GF 655/2, and Fehér besztercei) in Hungary (Szecskó, 2006). In our investigations, GF $8 / 1$ rootstock hardwood cuttings produced the greatest length of the root $(21.2 \mathrm{~cm})$. The IBA $2 \%$ treatment had the greatest impact on the average root length of cuttings $(17.4 \mathrm{~cm})$. The biggest root length was recorded in hardwood cuttings from GF 8/1 treated with $2 \%$ IBA $(23.7 \mathrm{~cm})$. The treatment with NAA $0.2 \%$ has no positive effect in increasing the rooting of cuttings, compared with the control. But, when separately analyzed, there was a positive influence on root length from this treatment in some of the rootstocks (GF 8/1, Alkavo, Gisela 4 and Gisela 5). Also, only the NAA treatment led to a statistically significant difference between the rootstocks with the greatest root length compared with most of the investigated rootstocks (Fig. 3.).

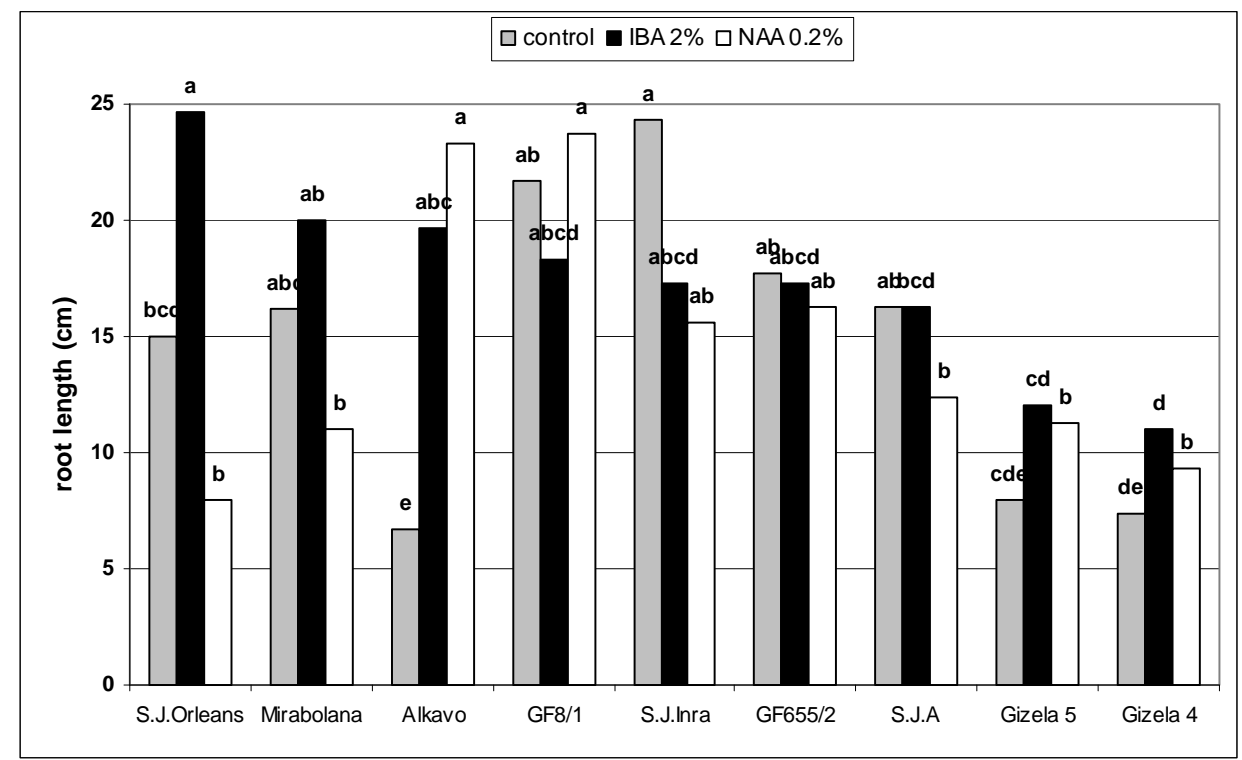

Fig.3. Root length of rooted hardwood cuttings.

The largest number of roots was obtained in rooted hardwood cuttings from the GF $8 / 1$ rootstock (13.2). The influence of auxin IBA $2 \%$ was crucial in the formation of the large number of roots (15.0) (Fig.4.).

The number of roots was statistically significantly highest under treatment with IBA $2 \%$ in hardwood cuttings from the Alkavo rootstock (27.3). Again, the auxin NAA had no higher positive influence on root formation in hardwood cuttings compared to the control, with the exception of some rootstocks (Alkavo and Gisela 5) (Fig.4.). 
The analysis of the root system of the cuttings shows that the greatest root mass was found in rooted cuttings from the Alkavo rootstock $(5.3 \mathrm{~g})$. The control variant had the statistically significantly greatest root mass of rooted hardwood cuttings from the Alkavo rootstock, compared with the other rootstocks. Generally, the treatment with IBA $2 \%$ had no important effect in increasing the root mass of rooted hardwood cuttings, unlike the treatment with NAA.

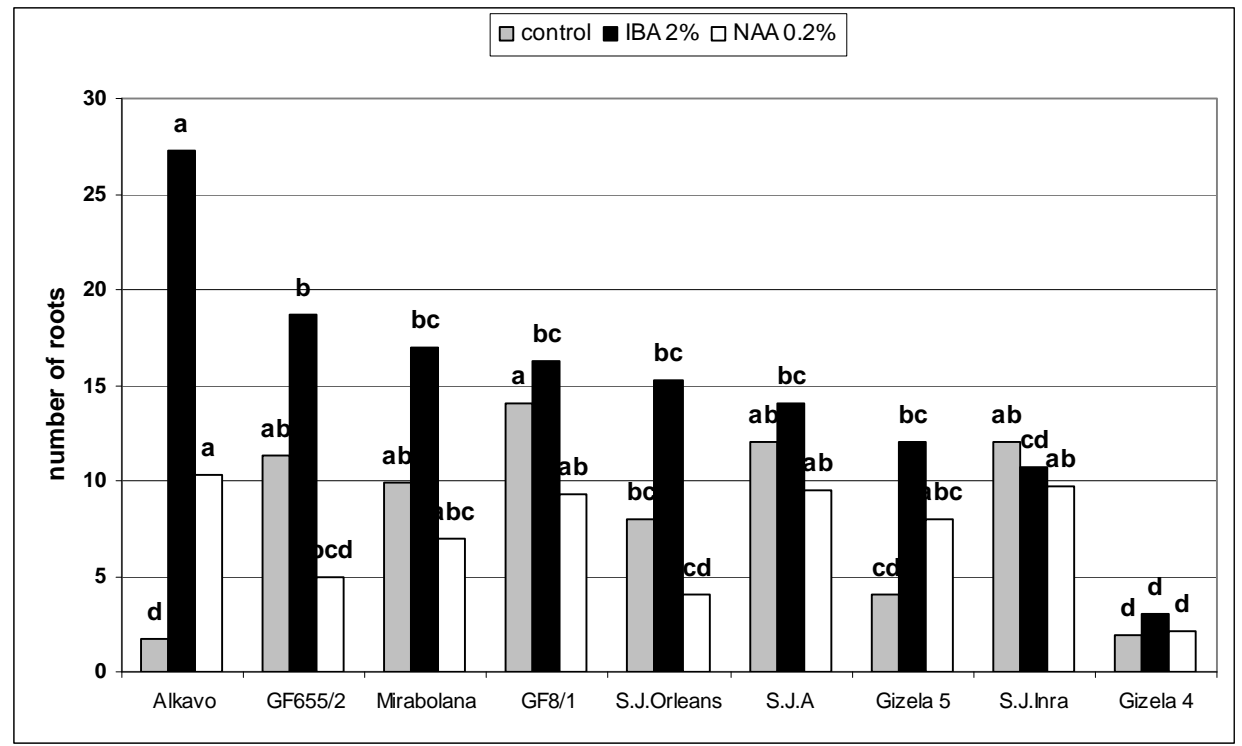

Fig.4. Number of roots in rooted hardwood cuttings.

\section{Conclusion}

Our investigations show that some rootstocks for stone fruit trees, especially plum/peach rootstocks (GF 8/1, GF 655/2, Mirabolana), have a high rooting ability. The rooting of hardwood cuttings was significantly more efficient than that of softwood cuttings. The use of auxin IBA $2 \%$ improves the rooting efficiency and root system quality of the rooted cuttings. We recommend using hardwood cuttings from the rootstocks GF 8/1, GF 655/2 and Mirabolana treated with biostimulator $2 \%$ IBA as an efficient and commercially reasonable method of rootstock propagation. 
Acta Agriculturae Serbica, Vol. XX, 39 (2015); 75 - 83

\section{References}

Ancu S., Dutu I., Indreas A.,.Iancu M., Ancu I. (2009). Vegetative Rootstocks Recently Registered and Promising Selections of the Stone Fruit Species. Bulletin UASVM Horticulture, 66(1)/ p.103-110.

Castro, L.A.S.D.E; Silveira C.A.P. (2003). Vegetative propagation of peach trees by layering. Revista Brasileira Fruticultura 25: 368-370.

Fachinello, J.C., Nachtigal J.C, Kersten. E. (1996). Fundamentals and practices in fruit production. Editora UFPEL,Pelotas, RS, Brazil.

Fachinello, J.C., Hoffmann A., Nachtigal. J. (2005). Propagation of Fruit Plants. Embrapa Informação Tecnológica, Brasília, DF, Brazil.

Hartmann H. T: et al. (1997): Plant propagation. New Jersey: Prentice-Hall. 211278.p.

López-Bucio, J. Cruz-Ramirez A., Herrera-Etrella. (2003). The role of nutrient availability in regulating rootarchitecture. Current Opinion in Plant Biology 6:280-287.

Lynch, J . (1995). Root architecture and plant productivity. Plant Physiology 109: 713.

Markovski A. (2012a). Investigation of vegetative characteritics of some pome fruit species rootstocks. XVII-th Conference on Biotechnology, Cacak, R Serbia, V.17(19), p.107-111.

Markovski A. (2012b). Rooting cuttings from pome fruit kinds rootstocks. Tribune, Kocani, Proceedings of Institute of Agriculture, R Macedonia T.28/29,V.28/29, p. 130-137.

Szecskó V., Hrotkó K., Stefanovits-Bányai É. (2006). Physiological factors influencing the rooting of plum rootstocks' hardwood cuttings. AGRONOMIJAS VĒSTIS (Latvian Journal of Agronomy), No. 9, LLU, p. 156-161.

Zarrouk, O.; Gogorcena Y., Gómez-Aparisi J., Betrán J.A, Moreno M.A. (2005). Influence of almond $\times$ peach hybrids rootstocks on flower and leaf mineral concentration, yield and vigour of two peach cultivars. Scientia Horticulturae 106: 502-514. 
Acta Agriculturae Serbica, Vol. XX, 39 (2015); 75 - 83

\title{
ISPITIVANJE MOGUĆNOSTI ZA PROIZVODNJU PODLOGA ZA KOŠTIČAVO VOĆE OŽILJAVANJEM REZNICA
}

\author{
Aleksandar Markovski, Melpomena Popovska, Viktor Gjamovski \\ Poljoprivredni institut -Skoplje, Univerzitet Sv. Ćirilo i Metodije, Skoplje, $R$. \\ Makedonija.
}

\begin{abstract}
Rezime
U ovom radu je ispitivan uticaj različitih biostimulatora (IBA and NAA) na ožiljavanje zelenih i zrelih reznica nekih podloga za koštičavo voće (Mirabolana, St. Julian A., St. Julian INRA, St. Julian Orleans, GF 8/1, GF 655/2, Alkavo, Gisela 4, Gisela 5, Weiroot 53 and Weiroot 158). Ogled je postavljen u eksperimentalnom stakleniku Poljoprivrednog instituta, Skoplje. Biostimulatori za ožiljavanje su primenjeni u tri varijante: a) IBA $2 \%$, b) NAA $0.2 \%$, c) IBA $2 \%$ bez hemijske zaštite. Podloga GF $8 / 1$ je imala najveći procenat ožiljenih reznica (50.8\%), dok kod nekih podloga (Weiroot 158 and Wieroot 53) ožiljavanje reznica je bilo zanemarljivo (1.6\%). Zrele reznice ispitivanih podloga su u proseku imale bolje ožiljavanje $(20.3 \%)$ u odnosu na zelene reznice $(6.0 \%)$. Prvi tretman (IBA 2\%) pokazao se kao najefikasniji za ožiljavanje reznica (23.1\%).
\end{abstract}

Kjučne reči: zelene reznice, zrele reznice, ožiljavanje 